\title{
PERTUMBUHAN KEMBALI DAN PRODUKSI BEBERAPA JENIS RUMPUT YANG DIBERI PUPUK ORGANIK
}

\author{
N.G.K. Roni, N.M. Witariadi, N.W. Siti dan I.G. Suranjaya \\ Fakultas Peternakan, Universitas Udayana, Denpasar \\ Email: gustironi_fapetunud@yahoo.com
}

\begin{abstract}
ABSTRAK
Produksi, kualitas dan ketersediaan tanaman pakan salah satunya ditentukan oleh kesuburan dan kesehatan tanah. Penggunaan pupuk kimia (anorganik) dalam periode yang lama merupakan salah satu penyebab degradasi lahan (Kartini, 2007), aplikasi pupuk organik merupakan langkah yang tepat dalam upaya menjaga kesuburan dan kesehatan tanah, serta mengurangi dampak negatif dari penggunaan pupuk anorganik. Penelitian yang bertujuan untuk mengevaluasi respons pertumbuhan kembali dan produksi beberapa jenis rumput terhadap pemberian pupuk organik dilakukan di rumah kaca menggunakan Rancangan Acak Lengkap pola split plot $3 \times 4$ dengan 3 kali ulangan.. Faktor pertama (main plot/petak utama) adalah jenis rumput yaitu Panicum maximum var. trichoglume (R1), Setaria splendida (R2), dan Pennisetum purpureum (R3); faktor kedua (sub plot/anak petak) adalah jenis pupuk organik yaitu tanpa pupuk (Po), pupuk kandang (P1), pupuk kompos (P2), dan pupuk kascing ( $\left.\mathrm{P}_{3}\right)$. Hasil penelitian menunjukkan bahwa tidak terjadi pengaruh interaksi antara jenis rumput dengan jenis pupuk organik terhadap pertumbuhan kembali dan produksi rumput Panicum maximum var. trichoglume, Setaria splendida, dan Pennisetum purpureum. Perlakuan jenis rumput berpengaruh nyata $(\mathrm{P}<0,05)$ pada semua peubah yang diamati, sedangkan perlakuan jenis pupuk organik hanya berpengaruh nyata $(\mathrm{P}<0,05)$ pada peubah jumlah anakan, jumlah daun, berat kering batang, berat kering total hijauan dan luas daun per pot. Berdasarkan hasil penelitian dapat disimpulkan bahwa tidak terjadi interaksi antara jenis rumput dengan jenis pupuk organik. Ketiga jenis rumput memiliki produktivitas yang berbeda, pertumbuhan tertinggi terjadi pada rumput yang diberi pupuk kascing, dan produksi tertinggi terjadi pada rumput yang diberi pupuk kompos.
\end{abstract}

Kata kunci: Pupuk organik, rumput panicum, rumput setaria, rumput gajah

\begin{abstract}
Production, quality and availability of forage one of which is determined by soil fertility and soil health. The use of chemical fertilizers (inorganic) in a period of time is one of the causes of land degradation (Kartini, 2007), application of organic fertilizers is the right step in maintaining soil fertility and soil health, and reduce the negative impact of the use of inorganic fertilizers. The study aimed to evaluate the response of regrowth and production of several species of grass to organic fertilizer conducted in a greenhouse using a completely randomized design split plot pattern $3 \times 4$ with three replications. The first factor (main plot / main plot) is a type of grass is Panicum maximum var. trichoglume (R1), Setaria splendida (R2), and Pennisetum purpureum (R3); The second factor (sub-plot / subplot) is a type of organic fertilizer that is without fertilizer (Po), manure (P1), compost ( $\left.\mathrm{P}_{2}\right)$, and vermicompost $\left(\mathrm{P}_{3}\right)$. The results showed that there was no interaction effect between type of grass with the type of organic fertilizer on the regrowth and production of grass Panicum maximum var. trichoglume, Setaria splendida, and Pennisetum purpureum. Treatment types of grass significant $(\mathrm{P}<0.05)$ on all observed variables, while the treatment of organic fertilizers only significant $(\mathrm{P}<0.05)$ in the variable number of tillers, number of leaves, stem dry weight, total dry weight of forage and leaf area per pot. Based on the results of this study concluded that there was no interaction effect between type of grass with organic fertilizer. The three types of grass have different productivity, highest growth in grass with vermicompost fertilizer and highest production in grass with compost fertilizer.
\end{abstract}

Key words: Organic fertilizers, panicum grass, Setaria grass, elephant grass 


\section{PENDAHULUAN}

Salah satu faktor pendukung dalam perencanaan produksi ternak adalah ketersediaan tanaman pakan, yang produktivitasnya tergantung kepada nutrisi tanaman yang sebagian besar diambil dari dalam tanah dalam bentuk unsur-unsur hara sehingga amatlah perlu menjaga kesuburan dan kesehatan tanah agar kuantitas, kualitas dan ketersediaan tanaman pakan dapat terus-menerus terjaga. Untuk itu, pengambilan unsur-unsur hara dalam bentuk hasil panen tanaman pakan harus diganti melalui pemberian pupuk. Penggunaan pupuk kimia (anorganik) dalam periode yang lama merupakan salah satu penyebab degradasi lahan (Kartini, 2007), karena dapat merusak sifat fisik, kimia dan biologi tanah (Supadma, 2006). Aplikasi pupuk organik merupakan langkah yang tepat dalam upaya menjaga kesuburan dan kesehatan tanah, serta mengurangi dampak negatif dari penggunaan pupuk anorganik.

Pupuk organik adalah pupuk yang sebagian atau seluruhnya terdiri atas bahan organik yang berasal dari tanaman atau hewan, dapat berbentuk padat atau cair yang digunakan mensuplai bahan organik untuk memperbaiki sifat fisik, kimia, dan biologi tanah (Suriadikarta dan Simanungkalit, 2006). Beberapa jenis pupuk organik yang umum digunakan adalah pupuk kandang, kompos, dan kascing. Menurut Abdul dan Indah (2005), pemberian pupuk kandang sapi 20 ton/ha mampu memperbaiki kualitas tanah yaitu meningkatkan kemampuan mengikat air dan ketersediaan N. Pada budidaya sayuran organik, aplikasi kompos pupuk kandang sebanyak 20 ton/ ha dapat memenuhi kebutuhan hara (Setyorini et. al., 2006). Begitu pula hasil penelitian Trisnadewi dan Wijana (2007) menunjukkan bahwa pemberian pupuk kandang 20 ton/ha menghasilkan produksi berat kering total hijauan jagung manis tertinggi dibandingkan pemberian 10 ton/ha dan 30 ton/ha.

Rumput benggala (Panicum maximum var. trichoglume), rumput Setaria (Setaria splendida), dan rumput gajah (Pennisetum purpureum) merupakan tanaman pakan unggul yang telah dikenal dan tersebar di masyarakat. Informasi tentang penggunaan pupuk organik pada tanaman pakan masih sangat terbatas, sehingga amat perlu dilakukan penelitian untuk mengevaluasi respons tanaman pakan tesebut terhadap aplikasi pupuk organik. Kemampuan rumput untuk tumbuh dan berproduksi setelah pemotongan atau penggembalaan merupakan salah satu faktor penentu keberlanjutan ketersediaan tanaman pakan dan indikator ketersediaan hara, sehingga perlu juga dievaluasi pertumbuhan kembali dan produksi dari tanaman yang diuji.

\section{MATERI DAN METODE}

Penelitian ini dilaksanakan di Rumah Kaca Laboratorium Tanaman Makanan Ternak Fakultas Peternakan Universitas Udayana, selama 2 bulan. Rumput yang digunakan adalah Panicum maximum var. trichoglume, Setaria splendida, dan Pennisetum purpureum. Tanah didapatkan dari lahan persawahan milik petani di Jalan Tukad Balian, Renon, Denpasar. Pupuk yang digunakan adalah pupuk kandang yang sudah matang berasal dari bekas kandang Sapi Bali milik peternak, pupuk kompos merek Temesi Compost dan pupuk kascing yang diproduksi oleh Bali Organik Association. Peralatan yang digunakan terdiri dari timbangan, ayakan, pisau dan gunting, pita ukur, penggaris, pot, dan kantong kertas.

Rancangan yang digunakan adalah Rancangan Acak Lengkap pola Split-Plot 3x4 dengan 3 kali ulangan. Faktor pertama (main plot/petak utama) adalah jenis rumput yaitu Panicum maximum var. trichoglume (R1), Setaria splendida (R2), dan Pennisetum purpureum ( $\mathrm{R}_{3}$ ); faktor kedua (sub plot/anak petak) adalah jenis pupuk organik yaitu tanpa pupuk (Po), pupuk kandang ( $\mathrm{P}_{1}$ ), pupuk kompos ( $\left.\mathrm{P}_{2}\right)$, dan pupuk kascing ( $\mathrm{P}_{3}$ ). Masing-masing perlakuan diulang tiga kali sehingga terdiri atas 36 unit percobaan. Dosis pupuk masing-masing pot adalah 20 ton/ha.

Pengamatan mulai dilakukan satu minggu setelah pemotongan pertama. Peubah yang diamati adalah tinggi tanaman, jumlah anakan, jumlah daun, berat kering daun, berat kering batang, berat kering total hijauan, berat kering akar, luas daun per pot, nisbah berat kering daun dengan berat kering batang, dan nisbah berat kering tajuk dengan berat kering akar. Data yang diperoleh dianalisis dengan Sidik Ragam (Program SPSS). Apabila perlakuan menunjukkan perbedaan yang nyata, maka dilanjutkan dengan Uji Duncan.

\section{HASIL DAN PEMBAHASAN}

Hasil analisis Sidik Ragam menunjukkan bahwa tidak terjadi pengaruh interaksi antara jenis rumput dengan jenis pupuk organik terhadap pertumbuhan kembali dan produksi rumput Panicum maximum var. trichoglume, Setaria splendida, dan Pennisetum purpureum. Perlakuan jenis rumput berpengaruh nyata $(\mathrm{P}<0,05)$ pada semua peubah yang diamati, sedangkan perlakuan jenis pupuk organik hanya berpengaruh nyata $(\mathrm{P}<0,05)$ pada peubah jumlah anakan, jumlah daun, berat kering batang, berat kering total hijauan dan luas daun per pot.

Rumput Panicum maximum var. trichoglume (R1) tumbuh lebih tinggi, memiliki jumlah anakan dan jumlah daun yang lebih banyak dibandingkan dengan 
Tabel 1. Pertumbuhan kembali dan produksi beberapa jenis rumput

\begin{tabular}{|c|c|c|c|c|}
\hline \multirow{2}{*}{ Peubah } & \multicolumn{3}{|c|}{ Jenis Rumput ${ }^{2)}$} & \multirow{2}{*}{ SEM $^{3)}$} \\
\hline & R1 & R2 & R3 & \\
\hline Tinggi Tanaman (cm) & $109.75^{\mathrm{a} 1)}$ & $35.58^{c}$ & $83.83^{b}$ & 1.94 \\
\hline Jumlah anakan (batang) & $14.00^{\mathrm{a}}$ & $13.42^{\mathrm{a}}$ & $4.83^{b}$ & 1.13 \\
\hline Jumlah Daun (helai) & $64.58^{a}$ & $55.17^{b}$ & $26.75^{c}$ & 3.13 \\
\hline Berat kering Daun (g) & $4.71^{\mathrm{b}}$ & $8.74^{\mathrm{a}}$ & $9.82^{a}$ & 0.38 \\
\hline Berat kering Batang (g) & $12.51^{b}$ & $10.43^{c}$ & $22.23^{a}$ & 0.71 \\
\hline Berat kering Total Hijauan (g) & $17.22^{b}$ & $19.18^{b}$ & $32.04^{\mathrm{a}}$ & 1.00 \\
\hline Berat kering Akar (g) & $11.18^{\mathrm{c}}$ & $24.98^{\mathrm{a}}$ & $17.95^{\mathrm{b}}$ & 1.62 \\
\hline Luas Daun Per Pot $\left(\mathrm{cm}^{2}\right)$ & $565.50^{b}$ & $736.83^{a}$ & $705.96^{\mathrm{ab}}$ & 50.11 \\
\hline Nisbah Berat Kering Daun dengan batang & $0.38^{\mathrm{b}}$ & $0.87^{\mathrm{a}}$ & $0.44^{\mathrm{b}}$ & 0.03 \\
\hline Nisbah Berat Kering Tajuk dengan Akar & $1.69^{a}$ & $0.81^{\mathrm{b}}$ & $2.01^{a}$ & 0.19 \\
\hline
\end{tabular}

\section{Ket:}

Nilai dengan huruf berbeda pada baris yang sama berbeda nyata $(P<0,05)$

R1: Panicum maximum var. trichoglume, R2: Setaria splendida, R3: Pennisetum purpureum

Standard Error of the Treatment Means

rumput Setaria splendida (R2) dan Pennisetum purpureum (R3) (Tabel 1). Hal ini menunjukkan bahwa rumput Panicum maximum var. trichoglume dapat tumbuh lebih baik dibandingkan dengan kedua jenis rumput lainnya. Kemampuan ini dikarenakan rumput Panicum maximum var. trichoglume memiliki sifat morfologi yang cenderung mengutamakan pertumbuhan tinggi batang dan jumlah anakan yang lebih banyak dibandingkan dengan jenis rumput lainnya, sesuai dengan pernyataan Mannetje dan Jones (2000), dan Sajimin et. al. (2004) bahwa rumput Panicum maximum var. trichoglume merupakan rumput tahunan berumpun dan bertandan, biasanya tegak, mencapai ketinggian 2 meter, sistem perakaran terdiri atas akar dangkal yang bercabang-cabang yang baik, batang ramping, 6-8 buku, daun-daunnya bagus dan lunak. Dibandingkan dengan rumput Setaria splendida (R2), rumput Pennisetum purpureum (R3) tumbuh lebih tinggi tetapi mempunyai jumlah daun dan jumlah anakan yang lebih rendah.

Rumput Pennisetum purpureum (R3) menghasilkan berat kering daun, berat kering batang, dan berat kering total hijauan yang lebih tinggi dibandingkan dengan perlakuan R1 dan R2 tetapi memiliki berat kering akar yang lebih rendah dibandingkan dengan R1 dan sedikit lebih tinggi dibandingkan dengan R2 (Tabel 1). Hal ini menunjukkan bahwa dengan berat akar yang sama, rumput gajah (Pennisetum purpureum) dapat menghasilkan produksi yang lebih tinggi dibandingkan dengan kedua jenis rumput lainnya. Hasil penelitian ini sesuai dengan yang dilaporkan oleh Nuriyasa dkk. (2013) bahwa berat kering daun, batang, dan total hijauan rumput gajah lebih tinggi daripada rumput setaria. Hal ini karena secara morfologi, rumput gajah mempunyai batang lebih besar dan ukuran daun lebih lebar sehingga lebih efektif dalam hal penyerapan unsur hara dan pemanfaatan radiasi matahari. Kondisi ini menyebabkan fotosintesis berjalan optimal yang berimplikasi terhadap lebih tingginya bahan kering yang dihasilkan oleh rumput gajah. Pendapat ini didukung oleh Budiana (1993) yang menyatakan bahwa makin tinggi laju fotosintesis maka makin tinggi karbohidrat dan protein yang dihasilkan tanaman sehingga berat kering juga makin tinggi.

Nisbah berat kering daun dengan batang rumput setaria (R2) lebih tinggi dibandingkan dengan pada perlakuan R1 dan R3 (Tabel 1). Hal ini karena berat kering daun rumput setaria lebih tinggi sedangkan berat kering batangnya lebih rendah. Nisbah berat kering daun dengan berat kering batang yang tinggi menunjukkan bahwa rumput tersebut mempunyai kualitas yang lebih baik karena kandungan karbohidrat dan proteinnya lebih banyak per berat kering total hiajaun yang sama. Nisbah berat berat kering tajuk dengan berat kering akar rumput gajah dan panicum lebih tinggi dibandingkan dengan rumput setaria (Tabel 1). Hal ini disebabkan oleh berat batang pada kedua jenis rumput tersebut lebih tinggi daripada berat batang pada rumput setaria.

Pemberian pupuk organik kascing ( $\left.\mathrm{P}_{3}\right)$ mampu meningkatkan secara nyata $(\mathrm{P}<0.05)$ rataan jumlah anakan dan jumlah daun rumput dibandingkan dengan kontrol (Po), dan tidak nyata dibandingkan dengan pemberian pupuk kandang (P1) dan kompos (P2) (Tabel 2). Hal ini karena pupuk organik kascing merupakan pupuk yang penguraiannya sangat baik, mengandung berbagai bahan yang dibutuhkan untuk pertumbuhan tanaman yaitu suatu hormon seperti giberellin, sitokinin dan auxin, serta mengandung unsur hara (N, P, K, Mg dan Ca) serta Azotobacter sp yang merupakan bakteri penambat $\mathrm{N}$ non-simbiotik yang akan membantu memperkaya unsur $\mathrm{N}$ yang dibutuhkan oleh tanaman dan juga mengandung asam humat yang bersama-sama dengan tanah liat berperan terhadap sejumlah reaksi kompleks baik secara langsung maupun tidak langsung dapat mempengaruhi pertumbuhan tanaman melalui pengaruhnya terhadap sejumlah proses-proses dalam tubuh tanaman (Rina, 2009) 
Tabel 2. Pertumbuhan kembali dan produksi rumput yang diberi pupuk organik dengan Akar

\begin{tabular}{lccccc}
\hline \multirow{2}{*}{ Peubah } & \multicolumn{5}{c}{ Jenis Pupuk Organik ${ }^{2)}$} \\
\cline { 2 - 5 } & P0 & P1 & P2 & P3 & \\
\hline Tinggi Tanaman (cm) & $\left.75.33^{\mathrm{a} 2}\right)$ & $78.78^{\mathrm{a}}$ & $77.22^{\mathrm{a}}$ & $74.22^{\mathrm{a}}$ & 2.24 \\
Jumlah anakan (batang) & $8.89^{\mathrm{b}}$ & $9.78^{\mathrm{ab}}$ & $11.44^{\mathrm{ab}}$ & $13.11^{\mathrm{a}}$ & 1.29 \\
Jumlah Daun (helai) & $42.00^{\mathrm{b}}$ & $47.11^{\mathrm{ab}}$ & $50.00^{\mathrm{ab}}$ & $56.22^{\mathrm{a}}$ & 3.62 \\
Berat kering Daun (g) & $7.16^{\mathrm{a}}$ & $7.82^{\mathrm{a}}$ & $8.20^{\mathrm{a}}$ & $7.84^{\mathrm{a}}$ & 0.43 \\
Berat kering Batang (g) & $14.39^{\mathrm{b}}$ & $14.50^{\mathrm{b}}$ & $17.02^{\mathrm{a}}$ & $14.31^{\mathrm{b}}$ & 0.82 \\
Berat kering Akar (g) & $17.02^{\mathrm{a}}$ & $18.08^{\mathrm{a}}$ & $18.42^{\mathrm{a}}$ & $18.62^{\mathrm{a}}$ & 1.87 \\
Berat kering Total Hijauan (g) & $21.54^{\mathrm{b}}$ & $22.32^{\mathrm{ab}}$ & $25.22^{\mathrm{a}}$ & $22.16^{\mathrm{ab}}$ & 1.15 \\
Luas Daun Per Pot (cm ${ }^{2}$ ) & $551.56^{\mathrm{c}}$ & $724.56^{\mathrm{ab}}$ & $787.61^{\mathrm{a}}$ & $614.00^{\mathrm{bc}}$ & 57.87 \\
Nisbah Berat Kering Daun & $0.53^{\mathrm{a}}$ & $0.63^{\mathrm{a}}$ & $0.52^{\mathrm{a}}$ & $0.58^{\mathrm{a}}$ & 0.04 \\
dengan batang & & & & & \\
Nisbah Berat Kering Tajuk & $1.48^{\mathrm{a}}$ & $1.40^{\mathrm{a}}$ & $1.75^{\mathrm{a}}$ & $1.39^{\mathrm{a}}$ & 0.22 \\
dengan Akar & & & & &
\end{tabular}

Ket:

Nilai dengan huruf berbeda pada baris yang sama berbeda nyata $(P<0,05)$ P0: Tanpa Pupuk, P1: Pupuk kandang, P2: Pupuk Kompos, P3: Pupuk Kascing Standard Error of the Treatment Means

Pemberian pupuk organik kompos (P2) dapat meningkatkan berat kering batang, berat kering total hijauan, dan luas daun per pot dibandingkan dengan tanpa pemberian pupuk sebagai kontrol (Po) (Tabel 2). Hal ini karena karena kompos merupakan sumber bahan organik dan nutrisi tanaman. Bahan dasar kompos mengandung selulosa $15-40 \%$, bahan mineral (abu) $3-5 \%$, selain itu terdapat bahan yang mudah larut pada air panas dan dingin (gula, pati, asam amino, urea, dan garam ammonium) sebanyak 2-30\%, dan 1-15\% lemak larut eter dan alkohol, minyak dan lilin (Setyorini et. al., 2006). Lebih lanjut disebutkan bahwa kompos dapat memperbaiki struktur tanah dengan meningkatkan kandungan bahan organik tanah dan akan meningkatkan kemampuan tanah untuk mempertahankan kandungan air tanah. Kemampuan ini dikarenakan kompos banyak mengandung mikroorganisme yang ditambahkan, akan tetapi mikroorganisme yang ada dalam tanah juga terpacu untuk berkembang. Aktivitas mikroba ini membantu tanaman untuk menyerap unsur hara dari tanah. Aktivitas mikroba tanah juga diketahui dapat membantu tanaman menghadapi serangan penyakit.

Perlakuan pupuk kandang secara nyata dapat meningkatkan luas daun pot dan cenderung dapat meningkatkan jumlah anakan, jumlah daun, berat kering batang, dan berat kering total hijauan, serta tidak berbeda nyata dibandingkan dengan pupuk kompos ( $\left.\mathrm{P}_{2}\right)$ dan kascing ( $\left.\mathrm{P}_{3}\right)$ (Tabel 2), hal ini karena pupuk kandang merupakan salah satu sumber bahan organik tanah yang sangat berperan dalam memperbaiki sifat fisik, kimia, dan biologi tanah. Pupuk kandang dapat mengurangi unsur hara yang bersifat racun bagi tanaman (Wiwik dan Widowati, 2010). Disamping itu pupuk kandang dapat meningkatkan pH, kadar Corganik serta meningkatkan ketersediaan nitrogen, fosfor, kalium dan unsur mikro bagi tanaman (Flaig, 1984). Ditambahkan oleh Sutedjo (2002), pupuk kandang juga mengandung unsurunsur makro (Nitrogen, Fosfor, Kalium, Kalsium, Magnesium, dan Belerang) juga mengandung unsurunsur mikro (Besi, Mangan, Boron, Tembaga, Seng, Klor dan Molibdinum) yang seluruhnya berfungsi menyediakan zat-zat makanan bagi kepentingan pertumbuhan dan perkembangan tanaman.

\section{SIMPULAN}

Berdasarkan hasil penelitian dapat disimpulkan bahwa tidak terjadi interaksi antara jenis rumput dengan jenis pupuk organik terhadap pertumbuhan kembali dan produksi rumput Panicum maximum var. trichoglume, Setaria splendida, dan Pennisetum purpureum. Ketiga jenis rumput memiliki produktivitas yang berbeda, pertumbuhan tertinggi terjadi pada rumput yang diberi pupuk kascing, dan produksi tertinggi terjadi pada rumput yang diberi pupuk kompos.

\section{SARAN}

Dalam budidaya tanaman pakan disarankan untuk memanfaatkan pupuk organik baik kompos maupun kascing sesuai dengan keadaan setempat, dan pupuk kandang sebaiknya terlebih dahulu dikomposkan atau dijadikan kascing. Perlu dilakukan penelitian dalam waktu yang lebih panjang untuk mendapatkan pengaruh optimal dari ketiga jenis pupuk organik.

\section{UCAPAN TERIMAKASIH}

Penulis mengucapkan terimakasih kepada Dekan Fakultas Peternakan, Universitas Udayana, Kepala Laboratorium Tumbuhan pakan, dan grup riset tumbuhan pakan yang telah memberikan fasilitas rumah kaca dan peralatan penelitian sehingga penelitian dapat terlaksana.

\section{DAFTAR PUSTAKA}

Abdul, S. dan Indah, N. 2005. Jurnal Ilmu Tanah dan Lingkungan. Universitas Gadjah Mada. Yogyakarta.

Budiana. 1993. Produksi Tanaman Hijauan Pakan Ternak Tropik. Fakultas Peternakan, Universitas Gajah mada. Yogyakarta.

Flaig, W. 1984. Soil organic Matter as a source of Nutrients. Organic matter and Rice. Los Banos Laguna, Philippines: International Rice Research Institute.

Kartini, N.L. 2007. Cacing Tanah dan Indikator Kesuburan Tanah. http://salam.leisa.info/index. php?url=getblob. php\&o_id=211154\&a_id=211\&_seq=0

Mannetje L.'t, Jones RM. 2000. Sumber Daya Nabati Asia Tenggara No. 4. Pakan. Raharjo I, Rahayu NM, Sulistyarini D, Uji T, Soetjipto NW, penerjemah; PT Balai Pustaka (persero) Jakarta bekerjasama dengan Prosea 
Indonesia, Bogor.

Nuriyasa I M, NN Candraasih K, A.A.A.S. Trisnadewi, E. Puspani, dan I.W. Wirawan. 2013. Peningkatan produksi rumput gajah dan setaria melalui pemupukan biourin. Pastura. Journal of Tropical Forage Science. 2(2). p . 93-96.

Rina D.C. Nahampun. 2009. Pengaruh Pemberian Pupuk Kascing dan Pupuk Organik Cair Terhadap Pertumbuhan Tanaman Kakao (Theobroma cacao L.) Laporan Penelitian. Fakultas Pertanian Universitas Sumatera Utara. Medan.

Sajimin, E. Sutedi, N.D. Purwantari dan B.S. Prawiradiputra. 2004. Agronomi Rumput Benggala (Panicum maximum jacq) dan Pemanfaatannya sebagai Rumput Potong. Lokakarya Nasional Tanaman Ternak. Balai Penelitian Ternak. Bogor.
Setyorini, S. Saraswati, R. dan Anwar, E.K. 2006. Kompos. Balai Besar Penelitian dan Pengembangan Sumberdaya Lahan Pertanian. Bogor.

Supadma. 2006. Kesuburan Tanah dan Pemupukan Tanah Pertanian. Pustaka Buana. Bandung.

Suridikarta dan R.D.M. Simanungkalit. 2006. Pupuk Organik dan Pupuk Hayati. Balai Besar Penelitian dan Pengembangan Sumberdaya Lahan Pertanian. Bogor.

Sutejo MM. 2002. Pupuk dan Cara Pemupukan. Rineka Cipta. Jakarta.

Trisnadewi, A.A.A.S., dan IW Wijana. 2007. Pengaruh Jenis dan dosis Pupuk Kandang terhadap Pertumbuhan dan Produksi Jagung Manis (Zea mays saccharata Sturt). Laporan Penelitian. Fakultas Peternakan Universitas Udayana. Denpasar.

Wiwik. H. dan L.R.Widowati. 2010. Pupuk Kandang. Balai Penelitian Tanah. Bogor. 